\title{
Literary Studies from Hermeneutics to Media Culture Studies
}

\author{
Siegfried J. Schmidt \\ Münster
}

Follow this and additional works at: https://docs.lib.purdue.edu/clcweb

0

Part of the Comparative Literature Commons, and the Critical and Cultural Studies Commons

Dedicated to the dissemination of scholarly and professional information, Purdue University Press selects, develops, and distributes quality resources in several key subject areas for which its parent university is famous, including business, technology, health, veterinary medicine, and other selected disciplines in the humanities and sciences.

CLCWeb: Comparative Literature and Culture, the peer-reviewed, full-text, and open-access learned journal in the humanities and social sciences, publishes new scholarship following tenets of the discipline of comparative literature and the field of cultural studies designated as "comparative cultural studies." Publications in the journal are indexed in the Annual Bibliography of English Language and Literature (Chadwyck-Healey), the Arts and Humanities Citation Index (Thomson Reuters ISI), the Humanities Index (Wilson), Humanities International Complete (EBSCO), the International Bibliography of the Modern Language Association of America, and Scopus (Elsevier). The journal is affiliated with the Purdue University Press monograph series of Books in Comparative Cultural Studies. Contact: <clcweb@purdue.edu>

\section{Recommended Citation}

Schmidt, Siegfried J "Literary Studies from Hermeneutics to Media Culture Studies." CLCWeb: Comparative Literature and Culture 12.1 (2010): <https://doi.org/10.7771/1481-4374.1569>

This text has been double-blind peer reviewed by $2+1$ experts in the field.

The above text, published by Purdue University Press (CPurdue University, has been downloaded 3680 times as of $11 /$ $07 / 19$.

This document has been made available through Purdue e-Pubs, a service of the Purdue University Libraries. Please contact epubs@purdue.edu for additional information.

This is an Open Access journal. This means that it uses a funding model that does not charge readers or their institutions for access. Readers may freely read, download, copy, distribute, print, search, or link to the full texts of articles. This journal is covered under the CC BY-NC-ND license. 


\section{PURDUE}

U N I V E R S I T Y UNIVERSITY PRESS <http://wWW.thepress.purdue.edu>

\section{CLCWeb: Comparative Literature and Culture}

ISSN 1481-4374 <http://docs.lib.purdue.edu/clcweb> Purdue University Press @Purdue University

CLCWeb: Comparative Literature and Culture, the peer-reviewed, full-text, and open-access learned journal in the humanities and social sciences, publishes new scholarship following tenets of the discipline of comparative literature and the field of cultural studies designated as "comparative cultural studies." In addition to the publication of articles, the journal publishes review articles of scholarly books and publishes research material in its Library Series. Publications in the journal are indexed in the Annual Bibliography of English Language and Literature (Chadwyck-Healey), the Arts and Humanities Citation Index (Thomson Reuters ISI), the Humanities Index (Wilson), Humanities International Complete (EBSCO), the International Bibliography of the Modern Language Association of America, and Scopus (Elsevier). The journal is affiliated with the Purdue University Press monograph series of Books in Comparative Cultural Studies. Contact: <clcweb@purdue.edu>

\section{Volume 12 Issue 1 (March 2010) Article 1 Siegfried J. Schmidt, "Literary Studies from Hermeneutics to Media Culture Studies" <http://docs.lib.purdue.edu/clcweb/vol12/iss1/1/> \\ Contents of CLCWeb: Comparative Literature and Culture 12.1 (2010) \\ <http://docs.lib.purdue.edu/clcweb/vol12/iss1/>}

Abstract: In his article "Literary Studies from Hermeneutics to Media Culture Studies" Siegfried J. Schmidt discusses aspects of hermeneutics, the systemic and empirical (contextual) approach to literature and culture, radical constructivism, and his postulates for the field of media culture studies. Schmidt describes his understanding of the transformation of literary studies towards media culture studies in the context of overall developments of society. His argumentation with regard to move from hermeneutics to media culture studies offers the postulate that research ought to be empirical and contextual in order to foster intuition, invention, innovation, and socially relevant scholarship. He concludes that the study of culture, literature, and media would further scholarship open to intuition, invention, innovation as input of and inspiration for creativity. 


\section{Siegfried J. SCHMIDT}

\section{Literary Studies from Hermeneutics to Media Culture Studies}

In this article I describe the long travel some literary scholars in Germany and in other countries have undertaken in order to proceed from traditional hermeneutics to empirical and contextual studies of literature and finally to media culture studies. My first sentence already indicates the complexity of what I am going to describe. First, the development I present has not been followed and subscribed by all or even by a majority of literary scholars and only some have taken this decision. However, in my view they succeeded to transform literary studies in a way and to a degree that has lately been discussed intensely on the international landscape of scholarship. This transformation occurred in the framework and in interaction with political, social, economic, and cultural developments since the end of World War II.

In Germany, the so-called Adenauer Era was dominated by the concentration of all energies on the material reconstruction of West Germany, heavily destroyed during the war. The "German economic miracle," assisted by the U.S. Marshall Plan and based on an effective capitalism and the ideology of neoliberalism, the aggressive anti-communist propaganda of the political leaders in West Germany, and the circumstances of the Cold War suppressed most attempts to thematize recent German history, World War II, and, above all, the Holocaust. West Germany became integrated in the Western world dominated by the USA, and it supported first steps towards European integration together with France. At the same time, the younger generation rediscovered the rich diversity of modern literature, art, and music since 1920, which had been deliberately suppressed during the Third Reich. Based on these discoveries some of them developed new tendencies in art which opposed aggressively traditional bourgeois, fascist, and communist arts, e.g. the Vienna School, Concrete Art and Poetry, abstract and experimental art, etc. Constructivism, suprematism, the Bauhaus, Dadaism, or surrealism fascinated the new generation as if these tendencies were contemporary and not historical movements. The political and economic leaders in West Germany clearly and quickly realized the strategic potential of abstract art favored above all by the elites in France and the USA. In their eyes, abstraction equalled exclusion of thematic contents or suppression of semantics. Supporting abstract arts thus allowed them to reach two aims: The supporters (i. e., the capitalists) could on the one hand gather cultural capital by economic investments in international art events like the Documenta in Kassel or the Donaueschinger Musikwochen and they could at the same time suppress - by the help of seemingly cultural arguments - a critical confrontation with the past (i.e., mostly their past). More or less the same tendency can be observed in German post-war literary studies. Scholars such as Richard Alewyn, Wolfgang Kayser, or Benno von Wiese, or philosophers like Martin Heidegger continued their work as if nothing had happened. Despite their sympathy with the nazi Reich and not discussed before the mid-1960s, they became prominent in the Bundesrepublik (Federal Republic of Germany) seemingly without any problems. They favored exclusively text-immanent analysis or hermeneutic approaches which excluded the contexts in which literary texts are produced, distributed, received, and post-processed. Literary texts were treated as if they were ontological self-contained entities whose interpretation could only be achieved by specially gifted scholars, since - as e.g., Kayser proclaimed - interpretation cannot be learned (5). As a consequence, literary scholarship was closely connected with structures of social hierarchies of leadership and followership: the "great interpreters" were adored and imitated - thus social patterns from recent German history were continued.

However, this was only one part of post-World War II West German culture. The part was the existentialist movement in philosophy and the arts which deeply influenced European societies. The thematization of absurdity, of fear, of being thrown into a senseless life facing nothingness articulated by authors such as Jean Paul Sartre or Albert Camus formed a radical contrast to the positivist minded mainstream in/of the West German society. The observation that technical and economic progress can be separated from socio-cultural progress was articulated by authors such as Max Horkheimer and Theodor W. Adorno in their critique of the culture industry based on a rereading of the writings of Karl Marx's Das Kapital. The post-war period came to an end in the 1960 s and for the first time since the war the economy fell into a crisis and the value system of the Adenauer Era collapsed. Values such as capitalism, parliamentarism, and democracy were put into question and the ideal of the bourgeois 
family and paternal education faded away. Protests against nuclear energy and the remilitarization of West Germany happened in the streets, outside the parliament, and in the political domain. Protesting students proclaimed a new society on the basis of socialist political ideals. Step by step the West German society changed into a post-industrial society with increasing media systems. The homogeneous bourgeois society changed into a pluralistic society which could no longer be directed by causal intervention and strategic planning. In sum, the 1960 s can be characterized as a time of severe generational conflicts: now, the nazi period, war, and the Holocaust became analyzed critically and condemned. Students called for political literature and a clear political engagement of literary studies and movements of sub-cultural, above all popular culture shaped the cultural system of post-war German society.

In literary studies new topics such as the social history of literature, trivial literature, comics, worker's and exile literature, and the literature and culture of East Germany were discussed and studies, topics which had been excluded by scholars subscribing to hermeneutics. In addition, new approaches and methods were developed or adopted, such as mathematical text analysis (Max Bense, A. Moles), French and East European structuralism and formalism (e.g., Greimas, Jakobson, Ingarden, Lotman, etc.), linguistic poetics, text linguistics, and semiotics. Insight into the social, political, and cultural embedding of literature fostered approaches such as critical literary studies (the Frankfurt School), materialist/Marxist literary studies, the social history of literature, history of reception, and effects of literary reading. Most of these approaches were no longer based upon hermeneutic philosophy; instead, analytic philosophy and the philosophy of language served as new meta-theoretical tools competing with Marxist and social critical orientations. This development produced a completely new situation in literary scholarship. The more or less homogeneous hermeneutic mainstream was replaced gradually by a number of rivalling approaches all of which claimed to be the most reasonable way to treat literature correctly and efficiently. The new situation resulted in a strict separation between the camps: On the one side traditional hermeneutics as a branch of the humanities was attacked by politically oriented scholars. On the other side approaches characterized by a strict disbelief in masters, authorities, and intuition, and a strict belief in rationality, explicitness and precise terminology as solid bases for teaching and learning literary scholarship in a scientific way appeared. An important lesson younger scholars learned at the time was to proceed from isolated items to embedded combinations. Regarding linguistic and literary topics led to the conclusion that the following aspects had to be considered: Words function when they are embedded in sentences; sentences function when embedded in texts, and texts can only function in verbal and nonverbal contexts in discourses and social situations. In other words, pragmatics was supposed to dominate syntax and semantics, an insight that belonged to the core subjects of Ludwig Wittgenstein's philosophy and the speech act theory from Austin to Grice.

In the late-1960s Norbert Groeben (University of Köln) and I started to develop an approach which later resulted in the theoretical and methodological framework called Empirische Literaturwissenschaft (ESL: Empirical Study of Literature; for a complete list of my publications see Lisiak and Tötösy de Zepetnek; for a bibliography of the field see Tötösy de Zepetnek, "Bibliography," see also "Systemic Approaches"). Based on the notion to regard literature as a social phenomenon, I constructed a theory of literary communication on the meta-theoretical basis of analytical philosophy and Karl Popper's critical rationalism. This theory fostered a crucial shift in literary studies, that is, the move from literary texts to the literary system. The main arguments of this theory of literature can be summarized as follows: The literary system is constituted by the mutual interaction of four domains of activities: 1) the production, 2) the distribution, 3) the reception, and 4) the post-processing of literary texts. Post-processing means referring to literary texts in terms of other media offers. This means that the literary text is necessarily embedded in social processes operating under social, cultural, political, and economic conditions of the respective society. In other words, literary phenomena are embedded in literary systems. Accordingly, literary texts are not regarded as objective entities but, rather, as results of highly conditioned social processes. Any scholarly treatment of texts, therefore, has to take into account the processes which result in the production or reception of literary texts.

In the early 1970s I was appointed as full professor of text theory and later on of literary theory at the University of Bielefeld. In the years to follow I happened to establish an interdisciplinary research group named NIKOL, whose members cooperated so closely that it is difficult to decide neatly who has 
contributed which idea to the final construction of the theory of the empirical study of literature (ESL; therefore, in what follows, I speak of we instead of I). The methodology of ESL was mostly borrowed from the sciences, especially from empirical social sciences. It works as follows: From an explicit theory hypotheses are derived. These hypotheses have to be operationalized in order to subject them to an empirical test. The results of these tests are then interpreted in the light of a presupposed theory. This methodology was applied to a number of topics in the 1970s and 1980s and the research results were published in book form in the book series "Konzeption Empirische Literaturwissenschaft" (Vieweg Verlag, later Westdeutscher Verlag). Here is an example: Psychologists tell us that there is a close connection between the personality or the mental state of a person and the way this person uses language. In one of our projects we tried to find out whether or not this holds true for poets, too. As an example we choose the Austrian poet Georg Trakl. We analyzed his complete work with the help of text linguistic tools and paralleled the results to all information we could find about his life and the development of his personality in the socio-cultural and political context of the Austrian-Hungarian monarchy. Based on the results of our study (see Rusch and Schmidt) we could demonstrate that there exists a strict correlation between the increase of psychological problems in Trakl's last years and an evident increase in the use of linguistic elements which express destruction, fear, and desperation.

Special emphasis was accorded in ESL to exact terminology/taxonomy. We tried to define all our concepts, such as literature, text, reception, understanding, meaning, fictionality, etc., in a clear-cut way for several reasons. First, we regarded exact terminology/taxonomy to be the very basis of teaching and learning literary studies in a rational way. Second, since we aimed at an interdisciplinary method in literary studies, we were convinced that interdisciplinary work presupposed exact terminology/taxonomy as the necessary prerequisite for reasonable discussion and empirical projects. This topic seemed to us and to many of our colleagues important, because one of the key words in the discussions about the future of German universities at that time was indeed "interdisciplinarity" (e.g., the University of Bielefeld was founded as a "reform University" based on the principle of interdisciplinarity in research and teaching and here again a characteristic relationship between tendencies of literary studies and developments in the social and political context can be observed). As the overall subject of study in ESL we choose the literary system composed of the social literary system and the semiotic literary system. The social system was defined by the self-organizing interaction of four types of processes, namely the production, distribution, reception, and post-processing of matters deemed literary by the agents in these processes (post-processing includes the analyzing, critiquing, translating, and interpreting of literary phenomena). We used the term "literary phenomenon" instead of "literary text/work" in order to indicate that only in relation to agents acting in social processes do phenomena result which were regarded to be literary according to applied criteria or concepts of literature. The social literary system was described in relation to other relevant social systems such as the religious, the political, or the education system. On the other hand, the term semiotic literary system was used to denominate the complete set of phenomena deemed literary texts by a social community in a specific period. Regarding the semiotic system, two interrelations have to be taken into account: the interrelations between the items in the semiotic system (intertextuality) on the one hand and the interrelation between semiotic items and value systems which single out these items as literary texts.

In our work in ESL we tried to reach the following objectives: theoreticity, empiricity, and applicability. We held the view that literary studies should be performed on the basis of explicit theories, e.g., semantic theories, reception theories, theories of personality or identity, theories of text analysis, etc. The second objective, empiricity, was surely the most problematic one. Because of the concentration on more or less isolated texts, literary studies in the past had gathered nearly no experience in empirical research and, until the advent of ESL, they had had no interest in empirical questions in the field of literature either. Consequently, one of the most difficult tasks of ESL was to raise the interest of literary scholars in empirical questions related to the research domain literary system which traditionally had been outsourced to literary sociology and psychology as a marginal aspect and apart from the core of literary studies, i.e., interpretation. A further task was to convince other literary scholars that empiricity had nothing to do with positivism or materialism. This task required a concept of empirical research centered on the notion of methodical constructions of facts ( $=$ facta, not data; and not positivism) which could be checked in an interdisciplinary way. We underlined again and again that 
empiricity should not be misunderstood as a search for objectivity or truth. Instead, the claim for empiricity signalled the intention to concentrate on social processes which resulted in literary phenomena through the activities of literary agents and to realize this concentration in an empirically intersubjective way.

The matter of applicability was an objective whose importance, too, can only be understood in the social and political context of the late 1970s and early 1980s. In that period the economic problems of welfare states like West Germany became evident. Oil crises and wars in several parts of the world indicated the beginning of what later on was called globalization. Caused by these developments representatives of society and politics were forced to scrutinize all social domains regarding their social necessity and efficiency. For example, in the disputes over nuclear energy, the natural sciences had lost much of their reputation because they proved to be unable to evaluate reliably the risks of nuclear technology. By the early 1980s, social studies and the humanities were confronted with uncomfortable critical questions such as: What are you scholars, what is your research good for? What does society get back for the money it spends for maintaining your expensive disciplines? Literary scholars either tried to ignore these questions, or they invented answers which convinced no one (including the scholars themselves). In ESL we tried to answer these questions by concentrating on topics which evidently had social impact and we asked: what is the function of literary instruction, what are the long term effects, and how do students understand this part of their education? There is enough empirical evidence to show that students nearly never read in their leisure time what they are forced to read and to interpret in school. What is going wrong in this respect? In one of our empirical research projects (see Hintzenberg, Schmidt, Zobel) we found that people in Germany stick to the concept of literature they have acquired in school for the rest of their lives. Thus, the more important it is what sort of literature they learn to love or to hate in school, especially when they grow up in multimedia societies with much competing media.

A further area we have been interested in was the reception and understanding of literary phenomena (see Meutsch). What goes on in the cognitive domain of students when they receive texts which are presented to them as literary texts? How do they handle linguistic complexity, and how does the interplay of cognitive and emotional processes work compared to the reception of non-literary texts? Do students really learn what might be coined as "difference management"? Do they really acquire the competence to deal with fictionality in a media society where the distinctions between reality, fiction, simulation, and virtuality become increasingly blurred? Our conviction has been and still is that a plausible and controllable application of research results in literary studies necessarily presupposes theoreticity and empiricity, as I postulated above. These aims are not arbitrary, since only after they have been realized in a sufficient way can literary scholars demonstrate to their colleagues in other disciplines, as well as to a general public why certain problems seem to be relevant not only for a couple of specialists, how they can be solved in a controllable way, and how the results can be applied to solve problems in other social areas as well.

In 1984 I was offered the opportunity to establish a research institute at the University of Siegen, called LUMIS (Institute for Empirical Literature and Media Research). In the following years we lectured widely in Germany and abroad and continued with the publication of articles and books. In addition, research fellows from several countries spent their sabbaticals at the institute and published their research results in the institute's monograph series Konzeption Empirische Literaturwissenschaft (Concept Empirical Study of Literature). Thus, step-by-step an international network of scholars developed which supported the ideas of ESL and worked on various topics in the field. In 1987 the International Society for Empirical Studies in Literature (IGEL) was founded during an international conference at Siegen University. Since then, biannual conferences are held all over the world and two scholarly quarterlies are devoted to the field, Poetics: Journal of Empirical Research on Literature, the Media and the Arts and SPIEL: Siegener Periodicum zur Internationalen Empirischen Literaturwissenschaft. ESL has become known as an alternative to other approaches in literary studies, but the majority of our colleagues in Germany did not accept it and there were at times rather hostile reactions and assessments published. Nevertheless, ESL occupied a notable position in the field of literary studies and in many encyclopedias and dictionaries entries about the field are included (see, e.g., Andringa; Barsch; Gorp and Delabastita; Tötösy de Zepetnek, "The Empirical Science"). Since the mid-1990s, while the theoretical and methodological framework of ESL received some attention in literary and cul- 
tural studies on the Anglophone landscape of scholarship, for example in the U.S., Franco Moretti although not referring to ESL - applied in his work on the novel the very principles of ESL or Matthew L. Jockers at Stanford University is collaborating with Hathi Trust: A Shared Digital Repository

<http://www.hathitrust.org/> to use the large amount of digitalized texts available in Google Books for various types of research for empirically based observations and interpretations: such developments in literary and cultural studies confirm the applicability of the theoretical base and methodology of the empirical study of literature as we have developed it.

In the 1980 s and 1990s two developments brought changes to ESL. First, there occurred social change which can be shortly characterized as follows. The introduction of private broadcasting (1980s) and the rapid growth of the internet (since 1994) gradually transformed industrial societies into media societies. This change fostered the process of globalization, changed the situation of labor, and influenced personal and social relations owing to new media, first via email and then followed by the internet. Media systems served as instruments by which societies observed themselves and by which media systems observed one another. People learnt the lesson that most of what they knew they knew from via media, to quote Niklas Luhmann: "What we know about our society, even about the world we live in, we know by the mass media" ( 9 ; my translation). Whatever strived for public attention had to happen in media and as a consequence, media societies became, strictly speaking, "media culture societies" where the daily use of media influences or even shapes our perception and thinking, our emotions, our memory, our modes of communication, as well as it influences political, economic, and educational practices. Since all and everything can be observed, everyone learns to know that everything could be seen and done in another way, i.e., the experience of contingency becomes omnipresent. The trend towards an untameable proliferation of changes in all domains of social and individual life together with the experience that intentional interventions into social developments had finally become impossible transformed media culture societies into "risk societies." This social change was accompanied by a philosophical change which influenced the future of ESL, namely radical constructivism (on this field see, e.g., Riegler <http://www.univie.ac.at/constructivism>). This philosophical school's designations include the constitutive role of observation and description, of self-organization and selfreference, and of autopoiesis. The crucial idea in the approach is that we ourselves construe our world, or to put it in another way that what we experience as objects in our world of experience results from processes we perform according to our conditions of action (see, e.g., Schmidt, ed. Der Diskurs des Radikalen Konstruktivismus; Schmidt, Kognitive Autonomie). While the majority of ESL scholars rejected the notion and tenets of radical constructivism and continued to operate on the basis of critical rationalism, we developed at LUMIS a radical constructivist version. In 1992 I published an article with the title "Literary Studies as Media Studies" and argued that in a media culture society any treatment of literature has to take into consideration that literature is but one medium among and competing with other media and that it is the whole media system of a society which establishes the difference of management in every usage of media offers. In other words, the literary system is embedded in the media system of a society. Above all, new media tend to transform traditional concepts of author, recipient, meaning, distribution, information, creativity, fiction, etc. What this may mean in the literary system can only be understood and defined in difference to their meaning in other media systems. From these arguments I concluded that it might be plausible to establish the field of media culture studies as a sort of portmanteau in which literary studies could find an appropriate place as a special branch concentrating on literary phenomena in the different media systems. In several articles in the 1990s I tried to explain how media culture studies might look like and how it might work (see also the field's integration and application in comparative cultural studies, e.g., Tötösy de Zepetnek, "Constructivism" and the aims of objectives of the humanities and social sciences quarterly CLCWeb: Comparative Literature and Culture <http://docs.lib.purdue.edu/clcweb>, as well as the Purdue University Press print monograph series of Books in Comparative Cultural Studies

<http://www.thepress.purdue.edu/series/comparative-cultural-studies >).

My concept of media culture studies is not identical with what has been developed in the United Kingdom and the USA as cultural studies. While there are similarities between the two fields, the philosophical basis of media culture studies differs from that in cultural studies, among others with regard to the theoretical framework of communication and media. Also, whenever a new approach is proposed, the question arises whether or not it should be institutionalized in terms of an academic disci- 
pline or not. My answer to this is an emphatic no. The reasons for my answer are these: History has shown that academic disciplines in the humanities tend to be restrictive in all respects in order to preserve their identity in competition with other disciplines. New ideas concerning research methods, new subjects or interdisciplinary co-operations are regarded with suspicion and they are more often than not rejected. For this reason I designate media culture studies in terms of a research program carried out by scholars who are interested in similar topics and who are able to co-operate on a similar metatheoretical, epistemological, and methodological basis (see Schmidt, "Medienkulturwissenschaft"). The basic area of problems of definition and designation are found in what I call media epistemology: How do we construe our realities via cognition and communication by media use? How do the technical and institutional conditions of a specific system of media or of networks of media systems shape our thinking, feeling, remembering, and value orientation? Is there an a priori set of media techniques? For example, one of the main tasks of media epistemology, in my view, is the elaboration of an explicit concept of culture (see my Histories and Discourses). The emergence of a society presupposes a framework of categories allowing for the semantic orientation of its members regarding all crucial aspects of social life. This system of semantic options consisting of categories and semantic differentiations, I call the model of reality of a society. It can be specified as the collective knowledge of the members of a society about their world which has been generated by common action and which has been systematized continually and corroborated by the experiences deriving from such actions. Collective knowledge is not to be understood as an entity but as the result of the processes of reflexivity, thus encompassing the cognitive "content" of the expectation(s) agents attribute to each other as collective knowledge in the sense of an operative fiction. A model of reality is established by the socialreflexive references of agents enacted through actions and communications and it is solidified as a symbolic-semantic order by/of language. Language permits the schematized designation and the designative constancy of categories and semantic differentiations for all the members of a society, in that it stabilizes collectively the possibilities of concrete references by means of semiotic materialities (signs). Collective knowledge is "passed on" to new members of a society via processes of socialization. It becomes collectively effective by virtue of the operative fiction that everyone expects everyone else to dispose of basically the same kind of knowledge. The operative fiction of collective knowledge may, therefore, indeed be hazardous for individual agents - they may misjudge the knowledge of others - but it is socially most efficient: One needs not know, it is enough to intend and this must suffice simply because we cannot look into the heads of our fellow humans.

Models of reality systematize the social interactions of agents with all the domains of action and reference considered important for and relevant to practical life, especially with environments and all their relevant resources and properties; with agents in their environments, who are important partners in interactions; with arrangements of socialization (institutions, organizations), i.e., with all socially controlled or constrained possibilities of action that are accepted or endured by agents; with emotions and their status, expressions, demands and restrictions; and with moral orientations (values) that are presumed/expected, admitted, or prohibited. The model of reality must necessarily be presupposed as valid for all members of the society so that agents may, in situation-specific operations of distinction, "make sense" by reference to this model and communicate such sense socially by means of linguistic references. Models of reality contain those possibilities of differentiation with which a society can operate in the five central dimensions listed above. They become operative in action only when there is a "program" that permits the socially prescribed realization of potential forms of reference to categories and semantic differentiations as concrete suppositions of distinction, i.e., which permit situation-specific selections from among the possible relations between suppositions and presuppositions. These concrete realizations combine cognitive, affective, and moral components. As selections, such suppositions of distinction are contingent and this contingency is inevitable because every supposition demands and admits simultaneously the choice of a particular option against the sense-constitutive background of all the excluded possibilities. The program of societally practised or expected references to models of reality - i.e., references to categories and semantic differentiations - their affective charge and moral weighting, and equally the program of admissible orientations in and by the model of reality of a society, is what I understand under culture. This designation of culture obeys the principle that the consciousness of the agents links itself to culture as the dynamic arrangement for references to models of reality and that it thus enacts itself. 
This train of thought makes clear that models of reality and cultural programs can only be envisaged in strict complementarity. As all categories could in principle be connected with all categories an ontological exclusion rule does not apply here - we need rules of selection and combination as well as criteria of compatibility in the form of a culture program, which effect a permanent reduction of the multitude of relations and thus produce given realities as contingent selections out of an infinite diversity. Only in terms of the unity of the difference between contingent selection and the infinite diversity of observables and un-observables a given reality gains processual identity. My deliberations about culture as a program are intended to make clear that "culture" as I understand it does not feature as an observable entity "existing as an object." Culture as a program realizes itself in concrete actions, as performed by agents in the form of offers of options and schematizations of options for purposes of reference to the model of reality valid for all the agents of a society who make use of precisely these functions and expect all other agents to proceed grosso modo likewise. Consequently, the workings of society presuppose the co-genesis of reality models and culture programs, both of which may differentiate themselves through successful referencing practices. Models of reality and cultural programs, however, do not only co-emerge, they form a mutually constitutive framework of interactive dependencies in the sense of general system theory.

A second domain concentrates on writing media histories. I use the plural in order to indicate that different media histories can be written, ranging from histories of media techniques to histories of mentalities. Of special interest, in my view, is a type of history which concentrates on changes evoked by the advent of a new medium in the private, as well as in the public sphere. Another important research area may be designated as a cultural history of media. Here research would concentrate upon the co-evolution of media and communication, the emergence of macro forms of communication such as literature, journalism, public relations and advertising, the rise of new genres, e.g., together with the development of the internet such as chats, blogs, twitter, social networks, video platforms (YouTube), etc., or forms of canonization. In this area single media offers are analyzed from a theoretical perspective of difference, i.e., in an interdisciplinary manner. In my view, this is the framework where literary studies ought to be located. Literary texts as special media offers produced and treated by a special social system, namely the literary system, play a specific role compared to all other media offers with regard to all relevant perspectives. Their production, distribution, reception, and postprocessing on the one hand differs from that of other media offers, on the other hand it has to be redefined with the advent of any new media system. Print, radio, television, or the internet have changed the material, communicative, and emotional conditions of all individual and social processes in which literary phenomena play a role. New genres such as computer poetry arise (see, e.g., Block, Heibach, Wenz; Hartling), literary texts are stored on and retrieved from the internet, literary phenomena have to compete with computer games, and there is the option to publish literary texts on the internet, etc.

A fourth research subject is trans- and intercultural problems. How can different cultural systems interact? What types of culture programs have been developed in history under various conditions? How did/do cultures colonialize each other and what types of hegemony can be observed? How can culture programs be differentiated and de-differentiated? How do processes of globalization transform local and national modes of identity and strangeness? Which types of culturality grow up in processes of globalization, e.g., interculturality or transculturality? Is it possible to perform media cultural studies not only in an interdisciplinary but also in an intercultural way? All of these have to respect that media culture studies can only operate in an autological and self-referential way (i.e., as a microsystem within a macro-system). Any description of cultures presupposes a culture of description. We communicate on communication via communication; we talk about media with the help of media and so on. That is to say, we direly need second-order observation - an integral component of radical constructivism - in order to find inquire into the criteria which regulate our observations and descriptions.

A good example with regard to the above postulate is the matter of human rights. Europeans and US-Americans tend to universalize their own conceptions of human rights, whereas Asians and Africans argue that in their culture program there exist human right concepts as well, and so different from the European and US-American concepts and practices. Here, again, globalization forces all interacting agents and institutions to attain a level of second-order observation in order to detect the 
blind spots of first-order observations, values, and emotions. Looking back to the initial question which might be the appropriate format of media culture studies the answer should have become clear: It can be best implemented as an interdisciplinary approach, as a platform of observation that integrates the expertise of all relevant disciplines in the format of a research program. And the long way from hermeneutics to the systemic and empirical (contextual) approach in the study of culture and literature should teach us the lesson that research in this program should be empirical research which is open for intuition, invention, innovation, as well as hermeneutic skills as input and inspiration of creativity.

\section{Works Cited}

Andringa, Els. "Literature: Empirical Studies." The Encyclopedia of Language and Linguistics. Ed. R.E. Asher. Oxford: Pergamon, 1994. Vol. 4, 2266-71.

Barsch, Achim. "Empirische Literaturwissenschaft." Literatur-Lexikon. Ed. Volker Meid. München: Bertelsmann, 1992. Vol. 13, 206-09.

Block, Friedrich, Christine Heibach, and Karin Wenz, eds. pOesis. Ästhetik digitaler Poesie / The Aesthetics of Digital Poetry. Ostfildern-Ruit: Hatje Canz, 2004.

Gorp, Hendrik van, and Dirk Delabastita, eds. "Empirische Literatuurwetenschap." Lexicon van literaire termen. Leuven: Wolters, 1991. 116-17.

Groeben, Norbert. "Methodologischer Aufriss der Empirischen Literaturwissenschaft." SPIEL: Siegener Periodicum zur Internationalen Empirischen Literaturwissenschaft 1.1 (1982): 26-89.

Hartling, Florian. "The Canonization of German-language Digital Literature." CLCWeb: Comparative Literature and Culture 7.4 (2005): <http://docs.lib.purdue.edu/clcweb/vol7/iss4/5/>.

Hintzenberg, Dagmar, Siegfried J. Schmidt, and Reinhard Zobel. Zum Literaturbegriff in der Bundesrepublik Deutschland. Braunschweig: Vieweg, 1980.

Horkheimer, Max, and Theodor W. Adorno. Dialektik der Aufklärung. Philosophische Fragmente. 1944. Frankfurt: Fischer 2000.

Kayser, Wolfgang. Das sprachliche Kunstwerk. Eine Einführung in die Literaturwissenschaft. Bern: Francke, 1948.

Lisiak, Agata Anna, and Steven Tötösy de Zepetnek. "Bibliography of Siegfried J. Schmidt's Publications." CLCWeb: Comparative Literature and Culture 12.1 (2010): <http://docs.lib.purdue.edu/clcweb/vol12/iss1/9>.

Liu, Yao-Kun. "Peking Opera and Grotowski's Concept of 'Poor Theatre'." CLCWeb: Comparative Literature

Luhmann, Niklas. Die Realität der Massenmedien. Opladen: Westdeutscher, 1996.

Meutsch, Dietrich. Literatur verstehen. Eine empirische Studie. Braunschweig: Vieweg, 1987.

Moretti, Franco. Atlas of the European Novel 1800-1900. London: Verso, 1998.

Riegler, Alexander, ed. Radical Constructivism (1996-): <http://www.univie.ac.at/constructivism>.

Rusch, Gebhard, and Siegfried J. Schmidt. Das Voraussetzungssystem Georg Trakls. Braunschweig: Vieweg, 1983.

Schmidt, Siegfried J. "Die Empirische Literaturwissenschaft. Ein neues Paradigma." SPIEL: Siegener Periodicum zur Internationalen Empirischen Literaturwissenschaft 1.1 (1982): 5-25.

Schmidt, Siegfried J. Foundations for the Empirical Study of Literature. Trans. Robert de Beaugrande. Hamburg: Buske, 1982.

Schmidt, Siegfried J. Histories and Discourses: Rewriting Constructivism. Trans. Wolfram K. Köck and Alison R. Köck. Exeter: Imprint Academic 2007.

Schmidt, Siegfried J. Kognitive Autonomie und soziale Orientierung. Konstruktivistische Bemerkungen zum Zusammenhang von Kognition, Kommunikation, Medien und Kultur. Frankfurt: Suhrkamp, 1994.

Schmidt, Siegfried J. Literaturwissenschaft als argumentierende Wissenschaft. München: Fink, 1975.

Schmidt, Siegfried J. "Medienkulturwissenschaft." Einführung in die Kulturwissenschaften. Ed. Ansgar Nünning and Vera Nünning. Stuttgart: Metzler, 2008. 351-69.

Schmidt, Siegfried J. "Why Literature is Not Enough, or Literary Studies as Media Studies." Emerging Visions of the Aesthetic Process: Psychology, Semiology, and Philosophy. Ed. Gerald Cupchik and János László. Cambridge: Cambridge UP, 1992. 227-43.

Schmidt, Siegfried J., ed. Der Diskurs des Radikalen Konstruktivismus. Frankfurt: Suhrkamp, 1987.

Tötösy de Zepetnek, Steven. "Bibliography of Work in Contextual (Systemic and Empirical) Approaches in Comparative Cultural Studies." CLCWeb: Comparative Literature and Culture (Library): <http://docs.lib.purdue.edu/clcweb/vol3/iss3/7>.

Tötösy de Zepetnek, Steven. "Constructivism and Comparative Cultural Studies." CLCWeb: Comparative Literature and Culture (Library): <http://docs.lib.purdue.edu/clcweblibrary/ccsconstructivism/>.

Tötösy de Zepetnek, Steven. "Systemic Approaches to Literature: An Introduction with Selected Bibliographies." Canadian Review of Comparative Literature / Revue Canadienne de Littérature Comparée 19.1-2 (1992): 2193. \& Edmonton: U of Alberta, U of Alberta Library ejournals (2009): <http://ejournals.library.ualberta.ca/index.php/crcl/article/viewFile/3075/2432>.

Tötösy de Zepetnek, Steven."The Empirical Science of Literature / Constructivist Theory of Literature." Encyclopedia of Contemporary Literary Theory: Approaches, Scholars, Terms. Ed. Irene R. Makaryk. Toronto: U of Toronto $\mathrm{P}, 1993.36-39$. 


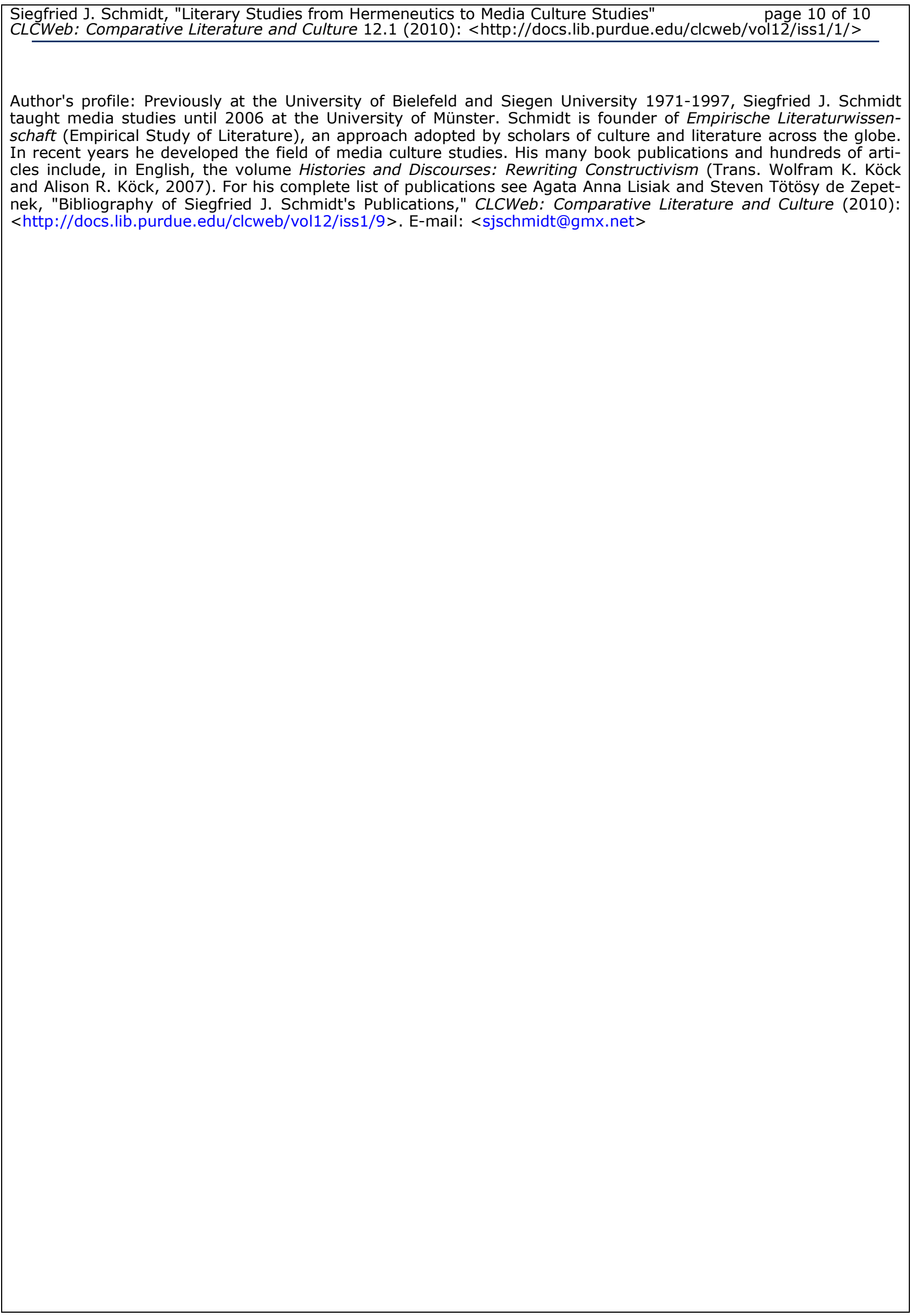

